JURNAL KETAHANAN NASIONAL

P-ISSN: 0853-9340, e-ISSN: 2527-9688

Online sejak 28 Desember 2015 di: http://jurnal.ugm.ac.id/JKN

VOLUME 22

No. 2, 25 Agustus 2016

Halaman 199-216

\title{
PERAN PEMUDA DALAM PENDAMPINGAN MAHASISWA DIFABEL DAN IMPLIKASINYA TERHADAP KETAHANAN PRIBADI PEMUDA (Studi di Pusat Layanan Difabel (PLD) UIN Sunan Kalijaga Yogyakarta)
}

\author{
Abd Mu'id Aris Shofa \\ Center for Culture and Frontier Studies (CCFS) Universitas Brawijaya \\ Email: arisshofa23@gmail.com
}

Bagus Riyono

Fakultas Psikologi Universitas Gadjah Mada

Sri Rum Giyarsih

Fakultas Geografi Universitas Gadjah Mada

\begin{abstract}
The researched aimed to determined how the role of youth, and the implications for the youth personal resilience in assisting students with disabilities at the Center For Disability Service (PLD) UIN Sunan Kalijaga Yogyakarta.

The method that used by the researcher in this study was descriptive qualitative method. Data collection techniques used three techniques, namely in-depth interviews, observation, and documentation.. The procedure of data analysis techniques in this research, namely the reduction of data, data display, and conclusions. The object of this research was the youth who became a companion for students with disabilities at the Center For Disability Service (PLD) UIN Sunan Kalijaga Yogyakarta.

From this research it could be noted, the role of youth in mentoring students with disabilities in the PLD UIN Sunan Kalijaga had a positive impact on the youth personal resilience. This was shown by the increasing of self-confidence attitude, adhering to the principle, had a sense of responsibility, crave togetherness, and a creative spirit.
\end{abstract}

Keywords: Role of Youth, Mentoring Students with Disabilities, Youth Personal Resilience

\begin{abstract}
ABSTRAK
Pemuda menjadi aset bangsa yang sangat penting bagi kelanjutan dalam kehidupan berbangsa dan bernegara, kemajuan suatu bangsa bisa dilihat dari kualitas pemudanya baik secara intelektualitasnya ataupun karakter pribadinya. Penelitian ini bertujuan untuk mengetahui bagaimana peran pemuda dan implikasi terhadap ketahanan pribadi pemuda dalam pendampingan mahasiswa difabel di Pusat Layanan Difabel (PLD) UIN Sunan Kalijaga Yogyakarta.

Metode yang digunakan oleh peneliti dalam penelitian ini adalah metode deskriptif kualitatif. Teknik pengumpulan data menggunakan tiga teknik, yaitu wawancara mendalam, observasi, dan studi dokumentasi. Prosedur teknik analisis data dalam penelitian ini, yaitu reduksi data, display data, dan mengambil kesimpulan. Objek dalam penelitian ini adalah para pemuda yang menjadi pendamping bagi mahasiswa difabel di Pusat Layanan Difabel (PLD) UIN Sunan Kalijaga Yogyakarta.
\end{abstract}


Dari penelitian ini diketahui, peran pemuda dalam pendampingan mahasiswa difabel di PLD UIN Sunan Kalijaga mempunyai dampak positif terhadap ketahanan pribadi pemuda. Hal ini ditunjukkan dengan adanya sikap rasa percaya diri yang bertambah, berpegang pada prinsip, memiliki rasa tanggung jawab, memiliki jiwa kreatif dan mendambakan kebersamaan. Dalam upaya untuk meningkatkan ketahanan pribadi pemuda yang tangguh dan baik maka program pendampingan terhadap mahasiswa difabel bisa digunakan sebagai salah satu metode atau cara untuk meningkatkan ketahanan pribadi pemuda.

\section{Kata kunci: Peran Pemuda, Pendampingan Mahasiswa Difabel, Ketahanan Pribadi Pemuda}

\section{PENGANTAR}

"Berikan aku sepuluh pemuda niscaya akan aku guncangkan dunia ini”. Demikian ungkapan yang pernah disampaikan Bung Karno dalam pidato tanggal 2 Januari 1932 Kongres Indonesia Raya di Surabaya . Makna yang bisa ditarik dari ungkapan pidato tersebut adalah bahwa pemuda menjadi modal sosial utama dalam pembentukan dan pertumbuhan serta perkembangan dari sebuah bangsa. Peran pemuda dalam negara dan bangsa sangat dibutuhkan sebagai pelaku untuk bisa melanjutkan cita-cita kemerdekaan Indonesia. Pemuda yang memiliki kesegaran gagasan, integritas tinggi, semangat perubahan dan progresivitas dan keluhuran cita-cita untuk membangun keadilan bersama.

Bercermin pada sejarah bangsa Indonesia, peran pemuda selalu mempunyai andil yang cukup besar dalam setiap momenmomen besar perjuangan bangsa Indonesia. Hal itu bisa dilihat dari peran dan fungsi pemuda Indonesia yang begitu kompleks dalam kehidupan berbangsa dan bernegara, di antaranya melalui perlawanan terhadap imperialisme dan kolonialisme, upaya dekonstruksi formasi sosial masyarakat, fungsi motor penggerak dan pengorganisasian serta melawan kekuatan luar yang mengancam keutuhan Negara Kesatuan Republik Indonesia (Dault, 2008).

Memasuki era modernisasi dan globalisasi yang tidak dapat dihindari, menjadi satu tantangan baru bagi pemuda saat ini untuk bisa tetap menjaga eksistensinya demi mewujudkan cita-cita para pendiri bangsa Indonesia terdahulu. Efek dari modernisasi dan globalisasi sangat rentan mempengaruhi sikap dan mental kalangan pemuda yang sebagian besar memandang bahwa menjelajahi dunia global dengan segala perangkat di belakangnya dirasa lebih membanggakan ketimbang bergumul dengan budaya lokal. Akibat dari semua ini identitas keindonesiaan pemuda mulai terkikis dan mendapat ujian yang besar.

Tujuan bangsa Indonesia yang secara nasional sudah tertuang di dalam pembukaan UUD 1945 alinea keempat yaitu melindungi segenap bangsa dan tumpah darah Indonesia, memajukan kesejahteraan umum, mencerdaskan kehidupan bangsa dan ikut dalam perdamaian dunia. Tugas untuk mewujudkan tujuan tersebut bukanlah terletak hanya pada pemimpin dan pemerintah saja, tetapi menjadi tugas semua elemen masyarakat bangsa Indonesia untuk bisa ikut mewujudkannya, termasuk pemuda di dalamnya supaya bangsa Indonesia menjadi bangsa yang unggul dan mampu bersaing dalam dunia global.

Pemuda merupakan bagian yang tidak dapat dipisahkan dari masyarakat bangsa. Kemajuan-kemajuan yang dicapai dari keberadaannya melukiskan kemajuan suatu bangsa. Dapat dikatakan bahwa prestasi 
pemuda adalah prestasi bangsa. Para generasi mudalah yang nanti akan memegang tongkat estafet kepemimpinan bangsa. Untuk itu diperlukan sumber daya manusia yang unggul, tangguh dan ulet serta mempunyai karakter yang baik. Jika pemuda bangsa mengalami kemunduran, hal tersebut ikut berdampak buruk pada kondisi bangsa. Oleh sebab itu,pemuda menjadi unsur yang sangat penting dalam perkembangan bangsa dan negara.

Pemuda dipandang sebagai satu generasi yang paling banyak memberikan harapan di masa depan. Pemuda memiliki dinamika, militansi, keberanian, kejujuran, dan kerelaan berkorban. Selain itu, pemuda memiliki kekhususan yaitu memiliki kecerdasan otak dan kemampuan berpikir tinggi yang diperolehnya dari pendidikan-pendidikan sebelumnya secara berturut-turut (Yayasan Mahasiswa Indonesia, 1997). Salah mengelola potensi pemuda akan menjadi hal yang negatif. Kesalahan pengelolaan potensi pemuda akan menjadi beban dan masalah dalam pembangunan bangsa dan negara. Pemuda yang menjadi aset pembangunan adalah mereka yang selalu mengerjakan hal-hal positif dan bermanfaat bagi lingkungannya. Begitu juga sebaliknya pemuda yang akan menjadi beban dan masalah adalah mereka yang terlibat dalam kegiatan-kegiatan negatif seperti tawuran, penyalahgunaan narkoba, sex bebas dan lain sebagainya (Irawanto, 2006).

Konstitusi atau Undang-Undang Dasar 1945 mengamanatkan bahwa setiap orang berhak mendapatkan pendidikan dan pemerintah wajib untuk membiayainya, selain itu dalam Undang-Undang Nomor 20 tahun 2003 Tentang Sistem Pendidikan Nasional, pasal 4 ayat 1 menyebutkan bahwa pendidikan diselenggarakan secara demokratis dan berkeadilan serta tidak diskriminatif dengan menjunjung tinggi hak asasi manusia, nilai keagamaan, nilai kultural, dan kemajemukan bangsa. Hal ini menunjukkan secara jelas bahwa penyelenggaraan pendidikan tidak boleh diskriminatif baik didasarkan atas fisik, ekonomi, ataupun sosial.

Praktek di lapangan yang sering ditemui adalah masih kurangnya perhatian terhadap kaum difabel dari segi pendidikan dan pekerjaan, bentuk-bentuk kekurangan tersebut mengambil berbagai macam, mulai dari syarat yang dibuat sampai fasilitas yang tidak tersedia. Hal tersebut dikarenakan masih adanya anggapan bahwa kaum difabel sering dianggap sebagai seseorang yang tidak berdaya, tentunya hal ini karena masih didasarkan pada penilaian fisik saja. Dengan kekurangan yang dimiliki ini kaum difabel sering dianggap sebagai seseorang yang tidak berdaya.

Tindakan yang sering mengabaikan atau mengucilkan terhadap kaum difabel yang sering terjadi dalam kehidupan sosial masyarakat semakin membuat kaum difabel menjadi terpinggirkan. Tindakan tersebut sudah masuk dalam pelanggaran hak asasi manusia. Regulasi Undang-Undang Nomor 39 tahun 1999 Tentang Hak Asasi Manusia, dalam pasal 42 mengamanatkan bahwa setiap warga negara baik itu lansia, difabel fisik atau mental memiliki hak dalam perawatan, pendidikan, pelatihan atas biaya negara guna menjamin kehidupan yang layak dan bermartabat.

Secara khusus kaum difabel juga dilindungi oleh undang-undang yang berkaitan dengan difabel yaitu tertuang dalam UndangUndang Nomor 4 tahun 1997 Tentang Penyandang Cacat (difabel) yang telah menegaskan bahwa kaum difabel merupakan 
bagian dari masyarakat Indonesia yang memiliki persamaan dalam kedudukan, hak dan kewajiban. Pasal 6 telah mengamanatkan setiap orang difabel berhak memperoleh pendidikan, pekerjaan dan kehidupan yang layak.

Universitas sebagai lembaga pendidikan formal menjadi tempat atau tujuan bagi setiap anak bangsa untuk mengenyam dunia pendidikan dan menimba ilmu sebanyakbanyaknya, akan tetapi melihat kondisi dilapangan masih banyak lembaga-lembaga pendidikan tinggi khususnya universitas yang tidak menyediakan fasilitas khusus bagi mahasiswa difabel, sehingga banyak kaum difabel yang tidak bisa melanjutkan pendidikan ke jenjang yang lebih tinggi. Saat ini dari pengamatan peneliti ada beberapa universitas yang sudah mulai menyediakan dan memberikan fasilitas bagi mahasiswa difabel, bahkan sudah mulai menyiapkan jalur khusus masuk untuk calon mahasiswa difabel.

Tulisan ini berusaha untuk mengakaji tentang bagaimana peran pemuda dalam pendampingan mahasiswa difabel di Universitas Islam Negeri Sunan Kalijaga dan bagaimana implikasinya terhadap ketahanan pribadi pemuda.

Dari uraian permasalahan tersebut, maka penelitian ini bertujuan untuk mengetahui peran pemuda dalam pendampingan mahasiswa difabel Universitas Islam Negeri Sunan Kalijaga dan mengetahui implikasinya terhadap ketahanan pribadi pemuda dalam pendampingan mahasiswa difabel UIN Sunan Kalijaga.

Metode penelitian menggunakan jenis kualitatif dengan pemaparan deskriptif. Adapun langkah-langkah analisis data yang dilakukan yakni (1) reduksi data yaitu data yang diperoleh di lapangan, dirangkum dan dipilih hal-hal yang pokok, dicari tema atau polanya, membuat catatan yang lebih rapi dan menyunting sehingga data tersebut mudah dikendalikan dan memberi gambaran yang lebih tajam tentang hasil pengamatan. (2) Display data yaitu pengelompokan data sejenis ke dalam sub tema atau tema dari kumpulan data tersebut. Hal ini dimaksudkan agar dapat melihat gambaran keseluruhannya atau bagian-bagian tertentu. (3) Mengambil kesimpulan atas data-data tersebut. Ketiga macam kegiatan analisis tersebut saling berhubungan dan berlangsung terus selama penelitian dilakukan. Hasil analisis data yang baik akan memberikan kemudahan bagi peneliti dalam mengemukakan data penelitian tersebut.

Pusat Layanan Difabel (PLD) UIN Sunan Kalijaga Yogyakarta menjadi lokasi penelitian karena UIN Sunan Kalijaga menjadi salah satu kampus inklusi yang sudah mampu memfasilitasi kebutuhan pendidikan bagi mahasiswa difabel di bawah naungan Pusat Layanan Difabel (PLD) dan keberadaan para pemuda pendamping atau relawan yang bersifat volunteer dalam pendampingan mahasiswa difabel tanpa adanya imbalan materi atau gaji yang diterima dalam kinerjanya.

\section{PEMBAHASAN}

\section{Pemuda Pendamping Di Pusat Layanan Difabel (PLD) UIN Sunan Kalijaga}

Sejak awal berdirinya Pusat Layanan Difabel (PLD) UIN Sunan Kalijaga berkomitmen untuk menerima dan memfasilitasi mahasiswa difabel, maka sejak saat itu pula keberadaan pendamping juga dibutuhkan. Pusat Layanan Difabel (PLD) 
di dalam menjalankan tugas-tugas pelayanan terhadap mahasiswa difabel yang ada di UIN Sunan Kalijaga tentu tidak bisa dilepaskan dari peran pendamping atau relawan (volunteer). Pendamping yang tergabung dalam PLD sendiri merupakan para mahasiswa aktif yang berada di lingkungan kampus UIN Sunan Kalijaga. Dalam proses pendampingan sendiri yang diterapkan bagi mahasiswa difabel meliputi pendampingan langsung (direct) dan pendampingan tidak langsung (indirect). Oleh karena itu untuk mengajarkan kemandirian bagi mahasiswa difabel tidak sepenuhnya dibantu oleh pendamping.

Keberadaan pemuda pendamping di Pusat Layanan Difabel (PLD) UIN Sunan Kalijaga benar-benar bersifat relawan (volunteer) yang bekerja atas dasar suka rela tanpa mendapatkan upah atau gaji dari kegiatan pendampingan. Hal ini berbeda dengan pendamping di Pusat Studi dan Layanan Disabilitas (PSLD) Universitas Brawijaya dimana para pendamping yang terlibat dalam proses pendampingan mahasiswa difabel mendapatankan hak berupa biaya transportasi dan komunikasi sesuai kontrak.

\section{Mahasiswa Difabel UIN Sunan Kalijaga}

Pada tahun ajaran 2015/2016 di PLD UIN Sunan Kalijaga mempunya 53 mahasiswa difabel dari berbagai macam jenis mulai dari tunanetra, tunarungu, tunadaksa, tuna grahita, dan cerebal palsy. Pusat Layanan Difabel (PLD) dalam menjalankan tugas dan layanan bagi mahasiswa difabel tidak bisa dilepaskan dari pemuda sebagai pendamping atau relawan (volunteer). Pendamping di PLD UIN Sunan Kalijaga sendiri merupakan mahasiswa aktif yang juga studi di kampus UIN Sunan Kalijaga yang berasal dari beberapa program studi dan fakultas. Keberadaan pendamping jelas sangat membantu tugas-tugas yang diemban oleh PLD UIN Sunan Kalijaga.

Dari beberapa kaum difabel yang diterima sebagai mahasiswa di UIN Sunan Kalijaga, pendampingan yang dilakukan oleh PLD UIN Sunan Kalijaga mempunyai beberapa kategori pendampingan. Hal tersebut dimaksudkan bahwa pendampingan tidak untuk memanjakan atau mengeksklusifkan mahasiswa difabel tetapi pendampingan dimaksudkan untuk mengajarkan kemandirian dan bisa melepaskan dari rasa ketergantungan.

\section{Motivasi Pemuda Dalam Pendampingan Mahasiswa Difabel}

Motivasi adalah suatu dorongan kehendak yang menyebabkan seseorang melakukan suatu perbuatan untuk mencapai tujuan tertentu (Rahmat, 2000). Motivasi berasal dari kata motif yang berarti dorongan atau rangsangan atau daya penggerak yang ada dalam diri seseorang. Motivasi didefinisikan sebagai kondisi internal yang membangkitkan seseorang untuk bertindak, mendorong untuk mencapai tujuan tertentu, dan membuat seseorang tetap tertarik dalam kegiatan tertentu. Hal demikian juga yang mendorong Anisa Dwi Rahma untuk mau menjadi pendamping di PLD UIN Sunan Kalijaga sejak semester 3 terlibat dalam proses pendampingan mahasiswa difabel. Berikut kutipan wawancaranya:

"kalau motivasi saya untuk mau menjadi pendamping karena suka belajar dengan teman-teman difabel dan berteman dengan mereka, bersinggungan dengan difabel itu memberikan banyak pelajaran pada saya. misalkan mengajarkan tentang semangat dan etos kerja dan juga belajar bahasa mereka ketika kita berkomunikasi dengan 
difabel tunarungu. Selain itu bisa membantu mereka untuk mendapatkan hak-hak yang mereka harus dapatkan misalkan membantu dalam mengakses pendidikan yaitu saat mengikuti pelajaran dalam perkuliahan atau ujian. Itu menjadi motivasi utama saya untuk mau bergabung dengan PLD" (Anisa Dwi Rahma: pendamping, wawancara 29 Januari 2016).

Selain itu juga motivasi dapat diartikan sebagai dorongan internal dan eksternal dalam diri seseorang yang diindikasikan dengan adanya hasrat dan minat, dorongan dan kebutuhan, harapan dan cita-cita, penghargaan dan penghormatan. Menurut Dzurotun Ni'mah Motivasi adalah sesuatu yang membuat seseorang bertindak melakukan hal yang positif dan bermanfaat bagi orang lain. Berikut kutipan wawancaranya:

" motivasi saya lebih kepada ingin menumbuhkan semangat pada diri sendiri dan bisa menambah pengalaman siapa tahu, ketika nanti saya terjun dalam dunia pendidikan sudah tidak asing lagi bagi dunia difabel sehingga ke depannya juga bisa banyak membantu bagi penyandang difabel. Selain itu dengan menjadi pendamping secara tidak langsung kita juga akan termotivasi oleh keberadaan mereka, mereka saja yang seperti itu mempunyai semangat dan tekad yang kuat untuk belajar dan pantang menyerah kenapa tidak dengan saya " (Dzurotun Ni'mah: pendamping, wawancara 3 Februari 2016).

Motivasi menjadi suatu kekuatan, tenaga atau suatu keadaan yang kompleks dan kesiapsediaan dalam diri individu untuk bergerak ke arah tujuan tertentu, baik disadari maupun tidak disadari. Motivasi yang demikian itu jugalah yang kemudian melatarbelakangi pemuda untuk terjun dan terlibat di dalam pendampingan mahasiswa difabel di Pusat Layanan Difabel UIN Sunan Kalijaga.

Motivasi seseorang dapat ditimbulkan dan tumbuh berkembang melalui dirinya sendiri (intrinsik) dan dari lingkungan (ekstrinsik). Motivasi intrinsik bermakna sebagai keinginan dari diri sendiri untuk bertindak tanpa adanya rangsangan dari luar. Motivasi intrinsik akan lebih menguntungkan dan memberikan keajegan dalam belajar. Motivasi ekstrinsik dijabarkan sebagai motivasi yang datang dari luar individu dan tidak dapat dikendalikan oleh individu tersebut. sehingga secara garis besarnya motivasi yang mendasari para pendamping untuk ikut dan bergabung di Pusat Layanan Difabel (PLD) UIN Sunan Kalijaga adalah karena ingin banyak belajar tentang difabel, berguna dan bisa saling membantu antara pendamping dan mahasiswa difabel.

\section{Bentuk Peran Dalam Pendampingan Mahasiswa Difabel}

Peran dalam proses pendampingan mahasiswa difabel merupakan wujud dari pelaksanaan dalam suatu proses pendampingan itu sendiri. Peran sendiri di sini bermaksud untuk melihat tindakan yang dilakukan oleh pendamping dalam membantu mahasiswa difabel. Tindakan yang dilakukan seseorang atau sekelompok orang dalam suatu peristiwa tersebut merupakan perangkat tingkah laku yang diharapkan, dimiliki oleh orang atau seseorang yang berkedudukan di masyarakat. Kedudukan dan peranan tidak dapat dipisahkan satu sama lain karena jika melihat dari pengertian tersebut keduanya saling berhubungan (Soekanto, 2009).

Pendamping dari mahasiswa difabel di PLD UIN Sunan Kalijaga mempunyai peran yang penting demi membantu kelancaran dan 
Abd Mu'id Aris Shofa, Bagus Riyono, dan Sri Rum Giyarsih -- Peran Pemuda Dalam Pendampingan Mahasiswa Difabel Dan Implikasinya Terhadap Ketahanan Pribadi Pemuda (Studi Di Pusat Layanan Difabel (PLD) UIN Sunan Kalijaga Yogyakarta)

mengajarkan kemandirian bagi mahasiswa difabel. Pendamping berperan sangat besar dalam proses kelancaran kegiatan perkuliahan yang dilaksanakan oleh mahasiswa difabel. Di PLD UIN Sunan Kalijaga sendiri sampai saat ini menerima mahasiswa difabel dari berbagai macam jenis mulai dari tunanetra, tunarungu, tunadaksa, tuna grahita, dan cerebal palsy.

Kegiatan yang dilakukan oleh Pusat Layanan Difabel (PLD) UIN Sunan Kalijaga Yogyakarta termasuk pendamping atau relawan di dalamnya, pada dasarnya terbagi menjadi dua macam, yaitu Direct Services dan Indirect Services. Direct Services berkaitan langsung dengan pendampingan secara langsung terhadap mahasiswa difabel, bersifat jangka pendek, praktis, teknis, dan layanan day to day. Sedangkan Indirect Services berkaitan tidak langsung dengan pendampingan mahasiswa difabel secara teknis, berkaitan dengan inisiatif advokasi (perubahan sosial), berdampak jangka panjang sehingga bernilai strategis.

Dari beberapa kaum difabel yang diterima sebagai mahasiswa di UIN Sunan Kalijaga, pendampingan yang dilakukan oleh PLD UIN Sunan Kalijaga mempunyai beberapa kategori pendampingan. Hal tersebut dimaksudkan bahwa pendampingan tidak untuk memanjakan atau mengeksklusifkan mahasiswa difabel tetapi pendampingan dimaksudkan untuk mengajarkan kemandirian dan bisa melepaskan dari rasa ketergantungan. Seperti yang disampaikan oleh Siddieq misalnya untuk jenis difabel tunarungu dilakukan pendampingan langsung karena peran pendamping dalam proses perkuliahan mempunyai tugas untuk mentransfer materi yang disampaikan oleh dosen, sedangkan untuk tunanetra pendampingan tidak langsung saat perkuliahaan dan pendampingan langsung saat ujian saja dan untuk tunadaksa pendampingan langsung saat perkuliahan dan monitoring saja saat ada orientasi mahasiswa baru di kampus. Berikut petikan wawancaranya:

"pendampingan yang dilakukan oleh
pendamping atau relawan kepada
mahasiswa difabel ini bertujuan untuk bisa
mengantarkan kepada proses kemandirian
dan bisa lepas dari rasa ketergantungan
terhadap orang lain. Dengan seperti itu
maka mahasiswa difabel nantinya ketika
keluar atau lulus bisa hidup mandiri dan
berdikari. Sehingga pendampingan itu
dilakukan tidak secara total. Misalnya untuk
mahasiswa difabel tunarungu, tunadaksa
saat perkuliahan pendampingannya bersifat
langsung atau pendampingan secara rutin
dan tunanetra hanya saat ujian. Tunarungu
dan tunadaksa pendampingan dilakukan
secara tidak langsung saat ujian dan kalau
tunanetra pendampingannya tidak langsung
saat perkuliahan". (Siddieq: pendamping,
wawancara 28 januari 2016).

Ketersediaan fasilitas yang ada dikampus UIN Sunan Kalijaga juga sangat membantu bagi proses pelaksanaan belajar mengajar khususnya bagi kaum difabel, sehingga kampus UIN Sunan Kalijaga pada 2013 mendapatkan penghargaan dari pemerintah sebagai kampus inklusif. Dengan menyandang status sebagai kampus inklusi maka kampus UIN Sunan Kalijaga sudah banyak memberikan fasilitasfasilitas bagi mahasiswa difabel dan juga cukup membantu peran pendamping dalam proses pendampingan terhadap mahasiswa difabel. Fasilitas-fasilitas yang sudah diberikan oleh kampus khususnya kepada mahasiswa difabel misalnya adanya jalur khusus bagi mahasiswa tunanetra dan tunadaksa membuat peran pendamping juga semakin mudah. 
Peran pendamping lainnya yang dilakukan di PLD UIN Sunan Kalijaga adalah harus mampu mengajarkan kemandirian kepada mahasiswa difabel, tidak memanjakan dan tidak memperlakukan secara khusus. Ini merupakan salah satu langkah positif yang dapat dilakukan oleh pendamping. Dengan seperti itu maka mahasiswa difabel bisa dan mampu untuk hidup mandiri. Dzurotun Ni'mah yang pernah mendampingi mahasiswa difabel tunarungu dan tunanetra dalam melaksanakan pendampingan lebih bersifat langsung kepada mahasiswa tunarungu dan bersifat tidak langsung pendampingan kepada mahasiswa tunanetra. Berikut wawancaranya:

"dalam proses pendampingan mahasiswa difabel yang pernah saya lakukan, berbeda antara jenis difabel tunarungu dan tunanetra. Kalau pendampingan mahasiswa tunarungu saya melakukannya ketika proses perkuliahan saja secara langsung, sedangkan untuk tunanetra pendampingannya bersifat langsung saat ujiannya, karena saat ujian tunarungu bisa membaca dan menulis, sedangkan untuk tunanetra karena mereka kan bisa mendengarkan saat perkuliahan dan biasanya mereka juga dibekali laptop yang memang sudah ada aplikasi yang bisa membantu dalam menulis materi kuliah hanya saja saat ujian peran pendamping membacakan soal dan menuliskan jawaban ". (Dzurotun Ni'mah:pendamping, wawancara 3 Februari 2016).

Pendampingan terhadap mahasiswa difabel tidak boleh menyalahi aturan-aturan yang sudah dibuat dan sepakati sebagai pendamping. Misalnya tidak boleh ikut mengintervensi dalam materi perkuliahan atau memberikan jawaban ketika pendampingan dalam ujian. Peran pendamping dalam pendampingan pada intinya tidak sampai memberikan perlakuan eksklusif dan tidak juga mendiskriminasikan mereka. Dalam proses pendampingan harus tahu bahwa pendamping itu ibarat tangan dan pena, artinya adalah sebagai alat yang hanya bertugas membantu menuliskan terkait hal perkuliahan akan tetapi tidak boleh ikut campur atau mengintervensinya, karena mahasiswa difabel juga punya fikiran yang bebas untuk berfikir dan independen. Ini dituangkan dalam etika pendampingan saat mahasiswa difabel menempuh ujian, sebagimana dalam gambar 1.

Gambar1

Etika Pendampingan Ujian Mahasiswa Difabel

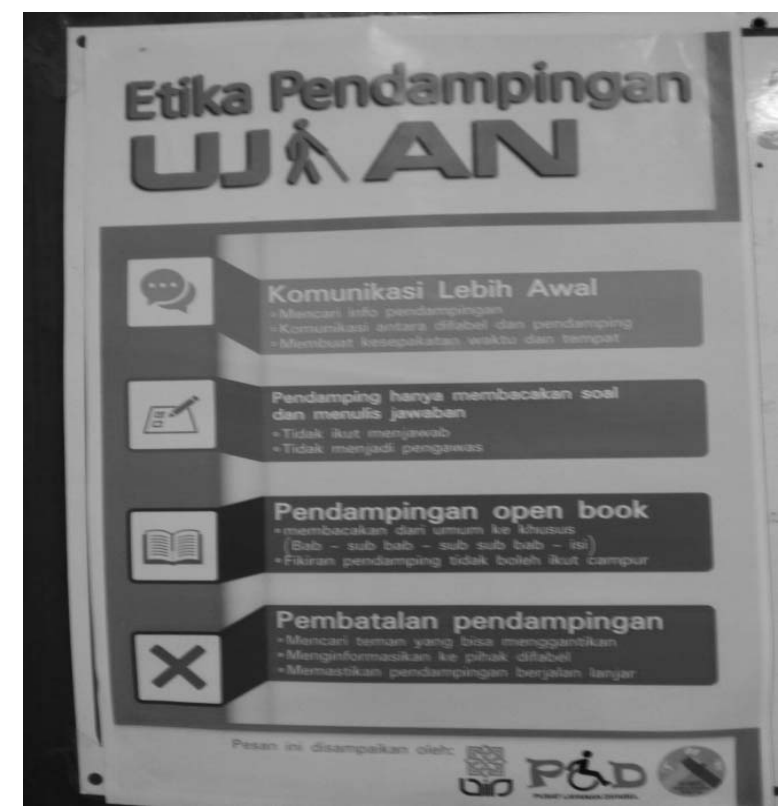

Sumber: Foto Pribadi Peneliti 2016

Dari pernyataan pada gambar 1 tersebut di atas dapat diketahui bahwa di dalam proses pendampingan mahasiswa difabel ada aturan-aturan yang harus dipatuhi oleh para pendamping supaya tidak melampaui batas-batas dalam pendampingan dan mampu mewujudkan tujuan pendampingan yaitu membantu proses kemandirian dan tidak justru 
membuat rasa ketergantungan atau adanya perilaku ekslusif terhadap mahasiswa difabel. Adapun penjelasan dalam etika pendampingan di atas dapat dijelaskan sebagai berikut.

Pertama, komunikasi lebih awal. Pendamping mencari info pendampingan dan menyesuaikan jadwal antara pendamping dan mahasiswa difabel. Setelah ada jadwal pendampingan maka harus ada komunikasi antara kedua belah pihak untuk membuat kesepakatan waktu dan tempat agar lebih memudahkan dalam hal pendampingan.

Kedua, pendamping sebagai mediator dan translator. Dalam proses pendampingan peran pendamping tidak boleh melampaui batas-batas yang berlebihan. Misalkan dalam proses pendampingan perkuliahan tunarungu peran pendamping hanya menyampaikan materi yang disampaikan dosen kepada difabel tunarungu tanpa merubah materi atau substansi. Dalam hal pendampingan ujian pendamping tidak berhak untuk ikut menjawab akan tetapi hanya membantu menuliskan jawaban saja. Selain itu pendamping tidak ikut menjadi pengawas dalam ujian.

Ketiga, pendampingan open book. Dalam hal pendampingan untuk mahasiswa tunanetra yang berkaitan dengan pembacaan literasi atau buku materi, pendamping melakukan pembacaan dari umum ke khusus (Bab-Sub Bab-Sub sub Bab-Isi). Selain itu dalam proses pembacaan materi fikiran dari pendamping tidak boleh ikut campur.

Keempat, pembatalan pendampingan Apabila dalam pendampingan, pendamping berhalangan untuk hadir atau tidak bisa melakukan pendampingan maka pendamping yang pertama wajib mencari pengganti teman pendamping lain yang bisa menggantikan, selain itu pendamping yang berhalangan mendampingi harus menginformasikan kepada mahasiswa difabel dan pendamping harus memastikan bahwa pendampingan pengganti bisa berjalan dengan baik dan lancar.

\section{Kendala Yang Dihadapi}

Keberadaan sumber daya manusia sangat menentukan keberhasilan dan kelangsungan dari suatu kegiatan atau aktivitas yang dilaksanakan. Begitu juga dengan pelaksanaan pendampingan yang dilakukan oleh PLD UIN Sunan Kalijaga terhadap mahasiswa penyandang difabel. Adanya keterbatasan sumber daya manusia yang dimiliki sebagai pendamping menjadi salah satu kendala yang dihadapi Pusat Layanan Difabel (PLD). Selain itu juga intensitas kehadiran dari para pendamping juga menjadi kendala, karena dalam prakteknya, seperti disampaikan oleh Siddieq koordinator pendamping PLD UIN Sunan Kalijaga, rata-rata tingkat kehadiran para pendamping itu hanya ketika ada suatu kegiatan tertentu saja, sehingga hal itu juga menyulitkan koordinator pendamping untuk bisa berkoordinasi dengan para pendamping untuk melakukan evaluasi.

Kendala-kendala lain yang dihadapi oleh pendamping juga bermacam-macam, dari informasi yang didapatkan peneliti selama proses penelitian ada dua macam kendala yang banyak dihadapi oleh para pendamping yaitu terkait dengan pemahaman bahasa isyarat dalam berkomunikasi dan kesibukan aktivitas pendamping. Adapun penjelasan lebih rinci dapat diikuti di bawah ini.

Pertama, pemahaman bahasa isyarat. Dalam kehidupan sehari-hari, tindakan komunikasi sering dilakukan karena komunikasi merupakan kebutuhan yang sangat mendasar untuk setiap manusia. 
Ada dua jenis komunikasi yang selama ini dapat dipahami yaitu komunikasi verbal dan komunikasi non verbal. Komunikasi verbal adalah penyampaian pesan atau informasi melalui bahasa atau lisan kepada orang lain, sedangkan komunikasi non verbal adalah penyampaian pesan atau informasi melalui isyarat atau ekspresi tubuh. Komunikasi adalah proses penyampaian suatu pernyataan oleh satu pihak kepada pihak yang lainnya atau banyak pihak supaya bisa terhubung dengan lingkungan yang ada di sekitarnya.

Secara mendasar, untuk membuat mengerti seseorang maka diperlukan komunikasi verbal karena komunikasi bisa terjadi jika ada kesamaan antara yang pemberi pesan dengan yang penerima pesan. Walaupun demikian, ternyata seseorang masih berkomunikasi antara kedua belah pihak dengan menggunakan bahasa tubuh, semisal mengangguk-angguk, menggeleng-geleng dan tersenyum (Jamila, 2005). Komunikasi yang sukses membutuhkan upaya dari semua orang yang terlibat dalam percakapan. Bahkan ketika orang dengan gangguan pendengaran atau tunarungu menggunakan alat bantu dengar, sangat penting bagi orang-orang yang terlibat dalam proses komunikasi secara konsisten menggunakan strategi komunikasi yang baik.

Demikian halnya dengan para pendamping yang memang masih baru berada di dunia difabel khususnya ketika bersinggungan dengan mahasiswa difabel tunarungu menjadi satu kendala tersendiri, apalagi bagi mahasiswa yang tidak mempunyai latar belakang yang secara langsung bersinggungan dengan difabel tunarungu. Pandangan ini disampaikan oleh Anisa Dwi Rahma dalam wawancaranya: "ketika menjadi pendamping teman-teman difabel di PLD ini, satu hal yang menjadi kendala utama adalah saat saya harus mendampingi teman yang tunarungu. Untuk memahami komunikasi dengan tunarungu perlu pemahaman dan pembelajaran yang ekstra, karena bahasa yang mereka pakai bahasa isyarat atau memakai gerak tangan, sehingga untuk mampu berkomunikasi secara baik dengan teman tunarungu saya harus banyak belajar kosakata baru dalam bentuk alphabet baik secara langsung dengan tunarungu atau secara otodidak" (Anisa Dwi Rahma: Pendamping, Wawancara 29 Januari 2016).

Berkomunikasi dengan teman difabel tunarungu memang perlu pemahaman bahasa yang baik, karena jelas berbeda dengan berkomunikasi secara verbal dengan orang normal. Berkomunikasi dengan teman tunarungu harus memahami bahasa isyarat yang menjadi alat untuk bisa berkomunikasi dengannya dan untuk mempelajari bahasa isyarat juga memerlukan waktu yang tidak sebentar karena adanya perbedaan bahasa dengan cara komunikasi secara verbal. Untuk mampu berkomunikasi dengan difabel tunarungu setidaknya seseorang harus mempunyai pemahaman dasar tentang huruf dasar alphabet yang digambarkan melalui gerakan tangan. Karena untuk berkomunikasi dengan tunarungu alat yang digunakan adalah dengan gerakan tangan yang membentuk kalimat melalui rangkaian huruf alphabet. Gambar 2 merupakan dasar gerak tangan yang membentuk huruf alphabet dalam bahasa isyarat.

Hal mendasar yang menjadi kendala dan dihadapi oleh banyak pendamping adalah terkait dengan pemahaman bahasa isyarat, sebab belajar bahasa isyarat memerlukan 


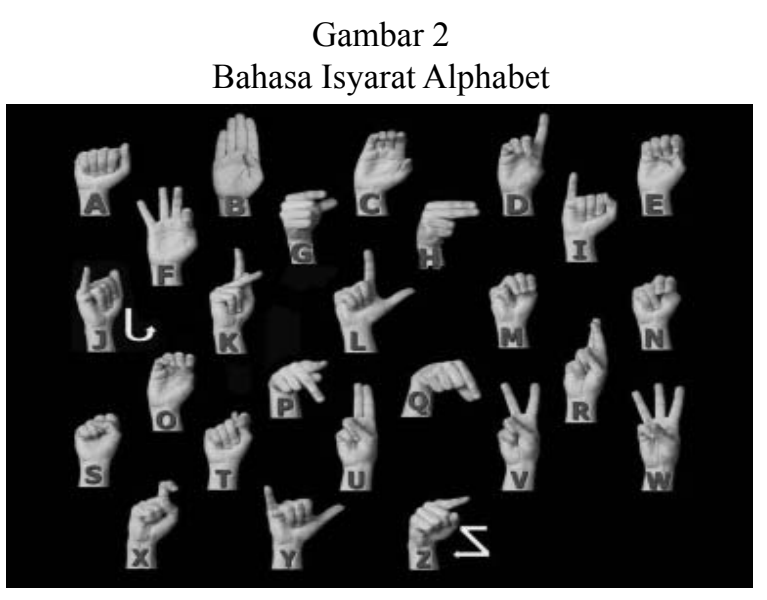

Sumber: http://pld.uin-suka.ac.id

banyak waktu dan harus benar-benar intens untuk mau mempelajarinya supaya tidak mudah lupa. Kendala yang selama ini banyak dialami adalah kurang intensnya dalam belajar dan rata-rata belajarnya adalah otodidak saja. Jadi dalam hal ini, kesamaan yang menjadi kendala para pendamping dalam proses pendampingan adalah tentang pemahaman dan penguasaan bahasa isyarat yang menjadi kunci utama dalam berkomunikasi dengan teman difabel khususnya difabel tunarungu. Untuk menghilangkan kendala dalam bahasa isyarat tersebut diperlukan proses belajar yang sangat intens dan perlu waktu yang cukup lama.

Kedua, aktivitas pendamping. Latar belakang dari aktivitas para pendamping yang ada di PLD semuanya adalah sebagai mahasiswa aktif yang ada di lingkungan kampus UIN Sunan Kalijaga dan mempunyai latar belakang keilmuan atau jurusan yang berbeda-beda. Selain aktif sebagai pendamping di PLD para pendamping juga mempunyai aktivitas lain di luar statusnya sebagai mahasiswa yang harus dan wajib mengikuti proses perkuliahan yang dilakukan. Kampus tidak hanya menjadi tempat untuk menuntut ilmu pengetahuan di dalam ruang kelas saja, tetapi juga tempat untuk menggali pengetahuan-pengetahuan yang lain dan kampus memfasilitasinya seperti unit kegiatan mahasiswa yang menyediakan banyak pilihan bagi mahasiswa untuk mengembangkan bakat dan kemampuannya di luar kelas.

Menjadi pendamping di PLD adalah suatu pilihan yang tentu sudah dipertimbangkan dengan matang. Ikut berbagi dan berpartisipasi dalam proses kemandirian mahasiswa difabel menjadi suatu yang sangat menarik dan bermanfaat, akan tetapi dalam proses pendampingan mahasiswa difabel ada aktivitas lain yang sering menjadi kendala pendamping misalnya saja kegiatan di pondok pesantren yang memang membatasi ruang gerak aktivitas selain kuliah. Seperti halnya aktivitas dari salah satu pendamping, Dzurotun Ni'mah, yang mengatakan bahwa selain kesibukan kuliah di kampus ada aktivitas di pondok pesantren juga yang harus diikuti, sehingga ini menjadi kendala dalam proses pendampingan, karena jadwal yang dari pondok kegiatan aktivitas sore dimulai sejak pukul 16.00 wib. Akibatnya, jika ada pendampingan yang di atas jam tersebut, maka sudah jelas tidak bisa melakukan pendampingan.

Selain aktivitas sebagai santri di pondok pesantren ada aktivitas di luar kampus yang juga menjadi kendala dalam pendampingan yaitu aktivitas di organisasi daerah (Orda), sehingga hal ini menjadi satu kendala tersendiri ketika ada jadwal yang berbarengan antara kegiatan pendampingan di PLD dan kegiatan di organisasi daerah. Pernyataan tersebut disampaikan oleh Mugiarjo, berikut kutipan wawancaranya:

"untuk kendala terkait aktivitas saya selain di PLD ini, karena saya berasal dari luar 
daerah dan saya di sini juga tidak mepunyai saudara maka untuk menjalin keakraban dan kekeluargaan di Yogja ini saya aktif di organisasi daerah Lampung. Kalau masalah perkuliahan saya sendiri tidak ada masalah karena sekarang saya sudah di semester akhir dan tinggal menyelesaikan tugas akhir saya yaitu skripsi, tetapi kebetulan kegiatan di organisasi daerah saya juga lumayan banyak jadi saya merasa bingung mengatur jadwal ketika ada kegiatan yang berbarengan antara pendampingan dan di organisasi daerah" (Mugiarjo: Pendamping, wawancara 5 februari 2016).

Jadi aktivitas dan kesibukan di luar kampus baik itu di pondok pesantren atau organisasi daerah merupakan satu kendala tersendiri ketika menjadi pendamping bagi mahasiswa difabel di PLD UIN Sunan Kalijaga. Akan tetapi hal itu tidak berlaku untuk semua pendamping, karena mayoritas pendamping yang hanya aktif sebagai mahasiswa ratarata tidak ada permasalahan dalam hal pendampingan di Pusat Layanan Difabel.

\section{Implikasinya Terhadap Ketahanan Pribadi Pemuda}

Implikasi dari peran pemuda pada PLD UIN Sunan Kalijaga terhadap ketahanan pribadi pemuda adalah sebagai berikut.

Pertama, memiliki rasa percaya diri.

Percaya diri merupakan salah satu aspek kepribadian yang sangat penting dalam kehidupan manusia. Orang yang mempunyai rasa percaya diri yakin atas kemampuan dirinya sendiri serta memiliki pengharapan yang realistis. Menurut Thursan (2002) percaya diri adalah kondisi mental atau psikologis diri seseorang yang memberi keyakinan kuat pada dirinya untuk berbuat atau melakukan sesuatu tindakan. Orang yang tidak percaya diri memiliki konsep diri negatif, kurang percaya pada kemampuannya, karena itu sering menutup diri.

Orang yang mempunyai rasa percaya diri yang baik berarti memiliki perasaan positif terhadap dirinya, mempunyai keyakinan yang kuat atas dirinya dan mempunyai pengetahuan akurat terhadap kemampuan yang dimiliki. Orang yang mempunyai rasa percaya diri yang baik, orang tersebut bukan hanya merasa mampu melainkan juga mengetahui bahwa dirinya mampu berdasarkan pengalaman dan pengetahuannya (Widarso, 2005).

Kepercayaan diri juga diartikan sebagai suatu perasaan atau sikap dan keyakinan atas kemampuan diri sendiri, sehingga dalam tindakan-tindakannya tidak terlalu cemas, merasa bebas untuk melakukan hal-hal yang sesuai keinginan dan tanggung jawab atas perbuatnnya, sopan dalam berinteraksi dengan orang lain, memiliki dorongan prestasi serta dapat mengenal kelebihan dan kekurangan diri sendiri (Lauster, 2002). Menurut Rahmat (2000) kepercayaan diri dapat diartikan sebagai suatu kepercayaan terhadap diri sendiri yang dimiliki oleh setiap orang dalam kehidupannya serta bagaimana orang tersebut memandang dirinya secara utuh dengan mengacu pada konsep diri.

Berdasarkan pendapat tersebut dapat disimpulkan bahwa percaya diri merupakan sikap individu yang yakin akan kemampuannya sendiri untuk bertingkah laku sesuai dengan yang diharapkannya sebagai suatu perasaan yang yakin pada tindakannya, tidak mementingkan diri sendiri dan cukup toleran, selalu optimis, gembira dan tidak ragu-ragu dalam mengambil keputusan.

Para pemuda yang menjadi pendamping di PLD UIN Sunan Kalijaga tentu juga memiliki rasa percaya diri, hal ini berbeda 
Abd Mu'id Aris Shofa, Bagus Riyono, dan Sri Rum Giyarsih -- Peran Pemuda Dalam Pendampingan Mahasiswa Difabel Dan Implikasinya Terhadap Ketahanan Pribadi Pemuda (Studi Di Pusat Layanan Difabel (PLD) UIN Sunan Kalijaga Yogyakarta)

sekali jika dibandingkan sebelum menjadi pendamping dan bergabung di PLD UIN Sunan Kalijaga. Seperti yang disampaikan oleh Anisa Dwi Rahma bahwa setelah menjadi pendamping rasa percaya dirinya semakin besar dan mempunyai dampak yang positif bagi pribadinya. Berikut kutipan wawancaranya:

"sebelum saya bergabung menjadi pendamping saya termasuk anak yang pemalu dan kurang bisa bersosialisasi, maka setelah saya bergabung di sini sebagai pendamping dan saya bergaul dengan teman-teman difabel saya merasakan hal positifnya yang pertama adalah rasa kepercayaan diri saya yang semakin besar dan itu sangat baik bagi saya untuk ke depannya, asalkan rasa percaya diri itu tidak berlebihan atau over confidence" (Anisa Dwi Rahma: pendamping, wawancara 29 Januari 2016).

Senada dengan pendapat di atas, para pendamping yang lain juga merasakan hal yang sama yaitu adanya perubahan sikap dalam pribadinya yang setelah menjadi pendamping dan berada dalam lingkungan teman-teman difabel semakin meningkatkan rasa kepercayaan diri yang ada dalam dirinya. Berangkat dari jurusan pendidikan dimana adanya tuntutan harus bisa praktek untuk menjadi guru di hadapan murid-murid, sebelumnya Dzurotun Ni'mah merasa sebagai pribadi yang tidak percaya diri dan sering kurang percaya diri jika harus berbicara di depan orang banyak. Ketika aktif menjadi pendamping ada perubahan positif dan tingkat rasa percaya dirinya semakin baik dan bagus, sehingga ini membuat salah satu indikator ketahanan pribadi dalam diri pemuda sebagai pendamping dapat terwujud yaitu dengan adanya dan meningkatnya sikap percaya diri.
Berikut kutipan wawancaranya: "jelaslah ya, di sini saya bisa merasakan dampak yang positif dan baik dalam diri saya setelah saya bergabung menjadi pendamping, rasa percaya diri saya semakin baik, karena basik saya pendidikan dan saya harus dituntut untuk bisa praktek mengajar dan harus berbicara di depan orang banyak maka rasa percaya diri atau pede itu semakin baik dan jelas itu berbeda sebelum saya aktif jadi pendamping dan bergabung di PLD ini" (Dzurotun Ni'mah:pendamping, wawancara 3 Februari 2016).

Pemuda yang menjadi pendamping di PLD UIN Sunan Kalijaga hampir secara keseluruhan dapat dipastikan mempunyai ketahanan pribadi yang baik dan posisitf yaitu mempunyai rasa kepercayaan diri. Hal itu juga yang dirasakan oleh pendamping Mugiarjo> Berikut kutipan wawancaranya:

“keberadaan saya sebagai pendamping di
sini juga mengajarkan banyak hal terhadap
diri saya, tidak hanya mengajarkan rasa
bersyukur saja, tetapi bergaul dengan teman
difabel mengajarkan saya banyak belajar
dari mereka tentang kesukaan membaca
buku. Yang dulunya saya tidak suka, setelah
bergaul dengan mereka saya semakin suka,
kemudian belajar sikap percaya diri, mereka
saja yang mempunyai keterbatasan merasa
percaya diri kenapa tidak dengan saya, itu
yang saya rasakan perubahan dalam diri
saya” (Mugiarjo: pendamping, wawancara
5 Februari 2016).

Peningkatan rasa percaya diri dalam diri seseorang jelas berimplikasi baik dalam pribadi tersebut. Rasa percaya diri yang baik berarti mempunyai nilai-nilai positif yang dirasakan dalam dirinya sebelum melakukan sesuatu dan setelah melakukan sesuatu. Pemuda yang menjadi pendamping 
mahasiswa difabel mampu merasakan hal positif dalam pribadinya yaitu dengan semakin meningkatnya rasa percaya diri dalam dirinya setelah aktif menjadi pendamping.

Kedua, berpegang pada prinsip. Prinsip dapat difahami sebagai ketentuan yang harus ada atau harus dijalankan atau juga dapat diartikan suatu aturan umum yang dijadikan sebagai panduan misalnya untuk dasar perilaku. Prinsip berfungsi sebagai dasar atau pedoman bertindak, bisa saja sebagai acuan proses dan dapat pula sebagai target capaian.

Prinsip adalah suatu pernyataan fundamental atau kebenaran umum maupun individual yang dijadikan oleh seseorang atau kelompok sebagai sebuah pedoman untuk berpikir atau bertindak (Samani dan Haryanto, 2011). Sebuah prinsip merupakan roh dari sebuah perkembangan ataupun perubahan, dan merupakan akumulasi dari pengalaman ataupun pemaknaan oleh sebuah obyek atau subyek tertentu.

Temuan penelitian di lapangan terkait dengan implikasi terhadap ketahanan pribadi pemuda sebagai pendamping, menunjukkan adanya korelasi atau hubungan yang sesuai dengan pernyataan tersebut di atas. Para pendamping mahasiswa difabel mempunyai karakter yang kuat terhadap prinsip yang dipegang dan diyakini. Artinya apa yang selama ini pendamping lakukan dan jalankan, mereka yakini sebagai sesuatu yang baik dan bernilai positif, baik itu bagi pribadinya sendiri atau pribadi orang lain.

Proses perubahan-perubahan yang ada dalam diri pribadi pendamping itu betul-betul bisa dirasakan setelah aktif dan bergabung menjadi pendamping di PLD, Sebelumnya pribadi Mugiarjo adalah pribadi yang bisa dinilai sebagai seorang yang mudah terpengaruh dalam hal sikap atau pengambilan keputusan, tetapi hal itu berubah ketika Mugiarjo sering terlibat aktif dalam pendampingan dan banyak bergaul dengan teman-teman difabel. Dalam hidup memang diperlukan prinsip sebagai pedoman atau acuan dalam bersikap dan bertindak, selama apa yang dilakukan dan laksanakan itu diyakini benar maka harus terus dipertahankan keteguhan prinsip tersebut.

Ketiga, memiliki rasa tanggung jawab. Samani dan Haryanto (2011) dalam rancangan pendidikan karakter menjelaskan bahwa karakter tanggung jawab adalah melakukan tugas sepenuh hati, bekerja dengan etos kerja yang tinggi, berusaha keras mencapai prestasi terbaik, mampu mengontrol diri dan mengatasi stres, disiplin, serta bertanggung jawab terhadap pilihan dan keputusan yang diambil. Karakter tanggung jawab tersebut, menurut Anton (2001) harus memenuhi 3 hal, yaitu (1) mampu mengendalikan diri, yang artinya memiliki tanggung jawab sebagai pribadi untuk menjalankan tugas semak-simal mungkin; (2) mengakui kesalahan dan kegagalan, yaitu memiliki keberanian menanggung risiko atas kegagalan atau kesalahan dalam mengambil keputusan; dan (3) memiliki kesungguhan dalam melayani orang lain.

Karakter tanggung jawab berarti mengembangkan keseimbangan antara hak dan kewajiban, berani menghadapi konsekuensi dari pilihan hidup dan mengembangkan sikap hidup bermasyarakat yang baik dan positif sesuai dengan aturan atau kaidahkaidah yang berlaku di dalam lingkungan. Menjadi pendamping adalah suatu pilihan dan sebenarnya siapapun juga berhak untuk tidak memilihnya, tetapi karena menjadi pendamping itu merupakan salah satu tugas 
mulia dan sekecil apapun tugas atau amanat yang diberikan maka harus bisa dilakukan dengan penuh tanggung jawab dan harus dengan sungguh-sungguh, keyakinan yang harus diyakini adalah bahwa semua yang dilakukan itu tidaklah akan sia-sia dan pasti bernilai positif untuk semuanya.

Faktor-faktor yang terkandung dalam tanggung jawab adalah usaha melaksanakan kewajiban dengan hasil kerja yang bermutu. kesediaan menanggung resiko, pengikatan diri pada tugas, keterikatan sosial dimana tindakannya harus memberikan dampak yang positif bagi kehidupan sosial, orang lain dan masyarakat.

Dapat dikatakan bahwa sumber dari tanggung jawab adalah di dalam diri individu sendiri. Hal ini menunjukkan suatu kemandirian yang mencirikan adanya suatu kematangan kepribadian bagi individu tersebut. Lebih lanjut, tanggung jawab mempunyai suatu orientasi yaitu orientasi untuk menentukan sikap, pilihan, keputusan kepada dirinya sendiri maupun sesuatu yang di luar dirinya atas tindakan-tindakan yang telah dilakukannya.

Keempat, memiliki jiwa kreatif. Menurut Jannah (2009), kreativitas dapat memberi kesempatan pada individu untuk mencari solusi dalam menghadapi berbagai tantangan dan tidak hanya terpaku pada kebiasaankebiasaan lama. Kreativitas diartikan sebagai kemampuan mental yang berhubungan dengan sikap ingin tahu dalam suatu bidang, dimana dihasilkan penciptaan atau penemuan sesuatu yang baru (Winardi, 1991). Bahkan kreativitas juga melibatkan unsur nilai atau kebutuhan pemikiran yang tepat untuk suatu situasi, dan kreativitas tersebut biasanya berhubungan dengan kemampuan dan kekuatan untuk mengembangkan ide-ide baru.
Suharnan (2005) menguraikan bahwa kreativitas sebagai proses menunjuk pada suatu aktivitas kognitif atau berpikir untuk mencari gagasan-gagasan baru atau orisinil dalam rangka memandang dan memecahkan suatu persoalan sedangkan kreativitas sebagai hasil karya menunjuk pada suatu pandangan bahwa sebuah karya dinilai kreatif apabila karya tersebut memiliki sifat baru dan berguna bagi lingkungan serta lebih bersifat umum.

Evans (1994) mengemukakan pendapat bahwa kreativitas adalah ketrampilan untuk menentukan pertalian baru, melihat subyek dari perspektif baru dan membentuk kombinasikombinasi baru dari dua atau lebih konsep yang telah tercetak, dalam pikiran. Pendapat senada mengarahkan pada pemikiran bahwa kreativitas adalah pengalaman mengekspresikan dan mengaktualisasikan identitas individu dalam bentuk terpadu dalam hubungan dengan diri sendiri, alam dan orang lain (Munandar, 2002).

Kreativitas mensyaratkan seseorang untuk bisa mengeksplorasi potensi dan mengkreasikan sesuatu hal yang baru untuk memperlancar suatu aktivitas. Kreativitas yang dibangun dari diri pemuda sebagai pendamping sangat berpengaruh terhadap pengalaman yang ada di lapangan. Belajar dari pengalaman, maka pendamping mempunyai inisiatif untuk menciptakan kreasi baru dalam pendampingan, khususnya ketika mendampingi teman difabel tunarungu, yaitu pendamping menciptakan kreasi sendiri untuk mempermudah dalam berkomunikasi dalam bahasa isyarat, misalkan menggunakan tulisan atau gambar, itu cukup efektif untuk pendamping dalam membantu teman-teman difabel.

Berangkat dari kendala yang dihadapi pendamping saat mendampingi, biasanya muncul ide-ide kreatif dalam pribadi pendamping, tidak hanya saat pendampingan 
tetapi juga saat menjalani kehidupan seharihari, sehingga proses pendampingan di PLD UIN Sunan Kalijaga turut serta membantu para pendamping untuk lebih memiliki jiwa kreatif baik dalam pendampingan maupun kehidupan sosial di masyaratakat. Kreativitas adalah kemampuan individu dalam membuat kombinasi baru berdasarkan data informasi atau unsur yang ada, berdasarkan data atau informasi yang tersedia, menemukan banyak kemungkinan jawaban terhadap suatu masalah, yang penekanannya adalah pada kualitas, ketepatgunaan dan keragaman jawaban, mencerminkan kelancaran, keluwesan dan orisinilitas dalam berfikir serta kemampuan untuk mengelaborasi suatu gagasan.

Berdasarkan penjelasan di atas terlihat jelas, bahwa para pendamping yang aktif di PLDUIN Sunan Kalijaga mempunyai implikasi terhadap ketahanan pribadi yang sesuai dengan indikator di atas yaitu memiliki jiwa kreatif. Sifat tersebut tidak hanya diterapkan ketika menjalankan tugas pendampingan saja, tetapi juga diterapkan ketika berada di lingkungan sosial masyarakat.

Kelima, mendambakan rasakebersamaan. Indikator untuk melihat ketahanan pribadi pendamping yang selanjutnya adalah mendambakan rasa kebersamaan. Hal ini terlihat jelas dari sikap dan perilaku para pendamping yang berada di PLD UIN Sunan Kalijaga yang memang memperlihatkan hal baik dan positif yaitu mendambakan rasa kebersamaan. Rasa bersama itu dibangun tidak hanya antara pendamping saja atau para difabel saja, tetapi di antara pendamping dan difabel. Berikut wawancara dengan Nurlaili.

"PLD ini bagi saya adalah keluarga baru di Yogyakarta, di sini kita tidak hanya diajarkan tentang bagaimana cara pendampingan tetapi lebih dari itu rasa kebersamaan itu yang membuat kita menjadi nyaman. Jadi pendamping itu tidak hanya membantu teman difabel tetapi juga membangun kebersamaan dengan semuanya menjadi sangat penting juga. bahkan meskipun tidak ada jadwal pendampingan kita semua sering janjian kumpul-kumpul di PLD” (Nurlaili:pendamping, wawancara 9 Februari 2016).

Kebersamaan memiliki makna sebuah ikatan yang terbentuk karena rasa kekeluargaan atau persaudaraan, lebih dari sekedar bekerja sama atau hubungan professional. Hubungan yang terbentuk antara pendamping dan penyandang difabel di PLD UIN Sunan Kalijaga bukan lagi berbicara tentang bagaimana tugas pendamping untuk bisa membantu teman difabel dalam mengakses pendidikan di kampus, tetapi sudah membentuk seperti keluarga dan saudara sendiri. Sebagai mahluk sosial manusia tidak bisa egois yang merasa bisa melakukan segalanya sendirian, yang merasa tidak membutuhkan orang lain, karena kehidupan itu suatu siklus sebab akibat. Ibarat sapu, kalau hanya satu batang lidi saja itu tidak akan banyak bermanfaat, tetapi kalau lidi itu disatukan menjadi sebuah sapu, maka akan sangat banyak manfaatnya. Itulah yang dirasakan pendamping dalam kebersamaan di PLD ini sehingga di antara mereka bisa saling menguatkan, berbagi dan saling membantu.

Kebersamaan yang dibangun di PLD UIN Sunan Kalijaga terbentuk karena adanya saling belajar, saling mendengar, saling berbagi dan saling peduli antara pendamping dengan teman difabel, maka di antara individu-individu pendamping terwujud rasa kebersamaan yang kuat dan erat, sehingga membentuk ikatan kekeluargaan dan persaudaraan. 
Penjelasan tersebut jelas memperlihatkan bahwa peran pemuda pendamping yang dilakukan terhadap mahasiswa difabel mempunyai dampak positif terhadap ketahan pribadi para pemuda, yaitu memiliki rasa percaya diri yang meningkat setelah aktif menjadi pendamping, berpegang pada prinsip yang diyakini akan kebenaran dan dijadikan sebagai pedoman dan acuan dalam kehidupan sehari-hari dalam bersikap dan bertindak, memiliki rasa tanggung jawab atas apa yang diamanatkan pada diri pemuda pendamping, memiliki jiwa kreatif dalam proses pendampingan sehingga tidak terpaku hanya pada satu aspek saja dalam kegiatan pendampingan, dan mendambakan rasa kebersamaan diantara para pemuda pendamping dan mahasiswa difabel sehingga hubungan yang terbangun bukan bersifat profesional antara pendamping dan yang didampingi, tetapi lebih bersifat kekeluargaan.

\section{SIMPULAN}

Berdasarkan uraian tersebut di atas dapat ditarik simpulan sebagai berikut.

Pertama, peran pemuda sebagai pendamping mahasiswa difabel di PLD UIN Sunan Kalijaga mempunyai dampak positif terhadap ketahanan pribadi pemuda. Selain itu tujuan dari pendampingan adalah untuk membantu membuat mandiri mahasiswa difabel, bukan justru memanjakan atau mengeksklusifkan mahasiswa difabel.

Kedua, peran pendampingan yang dilakukan mempunyai 2 jenis, yaitu pendampingan secara langsung (direct) dan tidak langsung (indirect). Saat proses perkuliahan bagi mahasiswa difabel jenis tunarungu dan tunadaksa khususnya yang memakai kursi roda, pendampingan dilakukan secara langsung di setiap proses perkuliahan. Pendampingan tidak langsung bagi mahasiswa difabel tunarungu dan tunadaksa dilakukan saat ujian. Untuk mahasiswa difabel tunanetra dilakukan pendampingan secara langsung saat ujian.

Ketiga, peran yang dilakukan dalam pendampingan telah mampu untuk meningkatkan dan menumbuhkan ketahanan pribadi pemuda, yang dilihat dari 5 indikator yaitu (1) memiliki rasa percaya diri, memiliki perasaan positif terhadap dirinya, mempunyai keyakinan yang kuat atas dirinya dan mempunyai pengetahuan akurat terhadap kemampuan yang dimiliki. (2) berpegang pada prinsip yang memang diyakini sebagai sesuatu yang baik dan benar, bersifat fundamental atau kebenaran umum maupun individual yang dijadikan oleh seseorang atau kelompok sebagai sebuah pedoman untuk berpikir atau bertindak. (3) memiliki rasa tanggung jawab dari amanat yang diberikan dan mengembangkan keseimbangan antara hak dan kewajiban, berani menghadapi konsekuensi dari pilihan hidup dan mengembangkan sikap hidup bermasyarakat yang baik dan positif sesuai dengan aturan atau kaidah-kaidah yang berlaku di dalam lingkungan. (4) memiliki jiwa kreatif dimana pendamping telah mampu membangkitkan dan melahirkan ide-ide baik yang berkaitan dengan pendampingan maupun dalam lingkungan sosialnya. (5) mendambakan rasa kebersamaan dimana kegiatan sebagai pendamping mahasiswa difabel telah mampu menumbuhkan semangat kebersamaan baik di antara pendamping ataupun teman difabel. Rasa kebersamaan tersebut terbentuk karena adanya saling belajar, saling mendengar, saling berbagi dan saling peduli antara pendamping dengan teman difabel, yang 
akhirnya membentuk ikatan kekeluargaan dan persaudaraan.

\section{DAFTAR PUSTAKA}

Anton, Adiwiyoto.,2001, Melatih Anak Bertanggung Jawab, Jakarta, Mitra Utama.

Dault, Adhyaksa., 2008, Spirit Pemuda: Upaya Memperkuat Negara, dalam Rekonstruksi Pemuda, Jakarta, Kemenpora RI.

Evans, James R., 1994, Berpikir Kreatif, Jakarta, Bumi Aksara.

Irawanto, Dwi., 2006, Catatan Emas, Jakarta, Kemenpora dan PT Excelcomindo.

Jamila,M., 2005, Special Education For Special Children, Jakarta: Hikmah.

Jannah, Amirratul., 2009. Membangun kreatifitas, (internet), http:// ameeratuljannah.wordpress.com, diakses 15 Februari2016).

Lauster, Peter., 2002, Tes Kepribadian, Jakarta, Bumi Aksara.

Munandar, S., 2002, Kreativitas dan keberbakatan. Strategi Mewujudkan Potensi Kreatif dan Bakat. Jakarta, Gramedia Pustaka Utama.

Rahmat, Jalaludin., 2000, Psikologi Komunikasi, Bandung, Remaja Rosda Karya.

Samani, Muchlas dan Haryanto., 2011, Pendidikan Karakter: Konsep dan Model, Bandung, PT Remaja Rosdakarya.

Soekanto, Soerjono., 2009, Sosiologi, Jakarta, CV. Rajawali.
Suharnan. T., 2005, Psikologi Kognitif, Surabaya, Srikandi.

Thursan, Hakim., 2002, Mengatasi Rasa Tidak Percaya Diri. Yogyakarta, Torren Book. Widarso, Wishnubroto., 2005, Sukses Membangun Rasa Percaya Diri "SelfConfidence”. Jakarta, Gramedia.

Winardi., 1991, Kreativitas Dan TeknikTeknik Pemikiran Kreatif Dalam Bidang Manajemen. Bandung, Citra Aditya Bakti.

Yayasan Mahasiswa Indonesia., 1997, Mahasiswa Dengan Pembangunan Mental dan Spiritual Dalam Repelita, Jakarta, Yasmindo.

\section{Peraturan Perundangan}

Undang-Undang RI Nomor 4 tahun 1997 Tentang Penyandang Cacat.

Undang-Undang RI Nomor 39 tahun 1999

Tentang Hak Asasi Manusia.

Undang-Undang RI Nomor 20 tahun 2003

Tentang Sistem Pendidikan Nasional

Undang-Undang RI Nomor 40 Tahun 2009

Tentang Kepemudaan.

\section{Wawancara}

1. Siddieq, tanggal 28 Januari 2016

2. Anisa Dwi Rahma, tanggal 29 Januari 2016

3. Dzurotun Ni'mah, tanggal 3 Februari 2016

4. Mugiarjo, tanggal 5 Februari 2016

5. Nurlaili, tanggal 9 Februari 2016 